\title{
Chewing It Over: Determining the Meaning of Edible in the Harmonized Tariff Schedule of the United States
}

\author{
Ben Baumgartner*
}

\section{INTRODUCTION}

"Definitions of the word 'edible' are scarcely essential, since its meaning is so well known." Initially, such a statement seems uncontroversial. Something is edible if it can be eaten. Yet, when the word is examined more carefully, its definition soon becomes much less clear. Is anything that can be eaten edible? Are poisonous berries edible? Is an airplane edible if someone eats it?" If "something that can be eaten" is not a workable definition of edible, what alternative, or alternatives, should be used?

Such questions are not posed merely as an intellectual exercise, but have important economic ramifications. When a good is imported into the United States, it is classified under the Harmonized Tariff Schedule of the United States (HTSUS). ${ }^{3}$ The word edible shows up repeatedly throughout the HTSUS, and whether a good is edible often affects its classification. A good's classification in turn determines in large part the applicable tariff rate. ${ }^{4}$ The applicable tariff rate ultimately affects how much the government may collect in tariffs and how much an importer must pay.

\footnotetext{
* J.D. Candidate, 2016, University of Kansas School of Law; B.A., 2012, Goshen College. I would like to thank Rice Distinguished Professor Raj Bhala for introducing me to international trade law and developing my interest and knowledge in the field, and for his helpful recommendations on this Comment. I would also like to thank Davina De La Torre, Matthew Schippers, Bryce Langford, and everyone on the Kansas Law Review Board who edited this Comment and made its publication possible.

1. United States v. Puttmann, 21 C.C.P.A. 135, 137 (1933).

2. See Michel Lotito, WIKIPEDIA, http://en.wikipedia.org/wiki/Michel_Lotito (last visited Oct. 2, 2015).

3. U.S. InT'L TRade Comm'N, Harmonized TarifF Schedule of the United States (2015) - REVISION 1, http://hts.usitc.gov/current [hereinafter HTSUS]; U.S. CUSTOMS: A Practitioner's Guide to Principles, Processes AND Procedures 39 (Michael D. Sherman et al. eds., 2009) [hereinafter U.S. CusTOMS].
}

4. U.S. Customs, supra note 3, at 39. 
A clear, simple, and accurate definition of the word edible is important for a number of reasons. First, clearly defining the word allows importers to accurately predict the tariff rate their goods will receive and, thus, the cost of importation. Unforeseen costs due to a higher-than-expected tariff rate may end up being passed on to consumers. Second, a simple definition promotes efficiency-during both the customs process and custom ruling appeals-because unnecessary analysis is eliminated. Lastly, a clear, simple, and accurate definition may save judicial resources by causing fewer appeals on the classification of goods..$^{5}$

Part II of this Comment provides an overview of customs law. It briefly examines the definition ${ }^{6}$ and history of tariffs, ${ }^{7}$ and explains the tariff collection process. $^{8}$ Part II also focuses specifically on the classification process, including tools for classifying goods ${ }^{9}$ and appeal procedures. ${ }^{10}$ Lastly, Part II demonstrates the importance of the word edible in classifying goods. ${ }^{11}$ Part III of this Comment discusses various tests for defining edible. This Part begins by looking at tests that should not be used to determine whether a good is edible, including whether the good is eatable, ${ }^{12}$ its appearance to the senses, ${ }^{13}$ whether it provides nourishment, ${ }^{14}$ whether its constituent parts are edible, ${ }^{15}$ and its principal use. ${ }^{16}$ Next, this Part explains tests that should be used, including whether the good may be eaten without harmful effects, ${ }^{17}$ whether it is habitually eaten, ${ }^{18}$ and whether it is actually eaten. ${ }^{19}$ Lastly, this Part briefly discusses the problem of whether a good must be edible "at the time of importation." 20

5. See Claire R. Kelly, Remnants of Recent Customs Litigation: Jurisdiction and Statutory Interpretation, 26 BROOK. J. INT'L L. 861, 874 (2001) (stating that classification and valuation issues "account for the majority of the customs decisions" in the Court of International Trade).

6. See infra Part II.A.

7. See infra Part II.B.

8. See infra Part II.C-D.

9. See infra Part II.E.

10. See infra Part II.F.

11. See infra Part II.G.

12. See infra Part III.A.1.

13. See infra Part III.A.2.

14. See infra Part III.A.3.

15. See infra Part III.A.4.

16. See infra Part III.A.5.

17. See infra Part III.B.1.

18. See infra Part III.B.2.

19. See infra Part III.B.3.

20. See infra Part III.C. 


\section{BACKGROUND}

\section{A. Tariffs}

A tariff is "a tax on imports." 21 The purpose of tariffs is primarily two-fold: to provide governments with revenue and to protect domestic markets by making the importation of foreign goods more expensive. ${ }^{22}$ Despite their widespread use, tariffs have been at times controversial. ${ }^{23}$ Even today, proponents on both sides of the issue hold strong beliefssome in favor of raising tariffs and others in favor of lowering them. ${ }^{24}$ Principally, the argument is between proponents of free trade, who believe lowering tariff rates will lead to increased prosperity, and proponents of protectionism, who believe higher tariff rates are needed to protect domestic industries and jobs. ${ }^{25}$

\section{B. History of Tariffs in the United States}

Tariffs have a long history in the United States. The first tariff act in the United States was the Tariff Act of $1789 .{ }^{26}$ This Act was the first major piece of legislation to be passed under the new U.S. Constitution and was "regarded throughout the country, on account of the general rejoicing it occasioned, as a second Declaration of Independence." 27 As the Act's first section states, the legislation was enacted "for the support of government, for the discharge of the debts of the United States, and the encouragement and protection of manufactures ...."28 Congress continued to pass new tariff laws, most notably the Smoot-Hawley Tariff Act in $1930,{ }^{29}$ which established the highest tariff rates in American history and triggered retaliatory tariff hikes by countries around the

\footnotetext{
21. Raj Bhala, International Trade LaW: TheOry and Practice 287 ( $2 \mathrm{~d}$ ed. 2001).

22. 25 C.J.S. Customs Duties $§ 9$ (2012).

23. Daniel K. Tarullo, Law and Politics in Twentieth Century Tariff History, 34 UCLA L. REV. 285,286 (1986).

24. Id. at 286, 310 n.85; Nadia Gire, The Trans-Pacific Partnership Agreement: A Revival in United States Trade Policy Reform, 20 CURRENTS: INT'L TRADE L.J. 60, 60 (2012).

25. Craig L. Jackson, Social Policy Harmonization and Worker Rights in the European Union: A Model for North America?, 21 N.C. J. INT'L L. \& CoM. REG. 1, 4 (1995); Tarullo, supra note 23, at 286.

26. Tariff Act of 1789 , ch. 2 , 1 Stat. 24; R. W. Thompson, The History of Protective TARIFF LAWS 67-68 (1888).

27. ThOMPSON, supra note 26 , at 67.

28. Tariff Act of 1789, § 1, 1 Stat. at 24.

29. Tariff Act of 1930, Pub. L. No. 71-361, 46 Stat. 590.
} 
world $^{30}$ Although tariff rates have decreased in recent years and are no longer a significant source of revenue, they serve as an important protective barrier in certain sectors, including agriculture. ${ }^{31}$ The fact that agricultural products still receive relatively high tariff protection is significant because this means that more money is at stake in disputes over whether a product is edible or not.

\section{Harmonized Tariff Schedule of the United States}

The current tariff system in the United States is the Harmonized Tariff Schedule of the United States (HTSUS), codified in 1988 at 19 U.S.C. $\S 1201$ as part of the Omnibus Trade and Competitiveness Act of $1988 .^{32}$ The HTSUS resulted from an international effort to unify, or harmonize, the classification of imported goods. ${ }^{33}$ The HTSUS classifies any good imported into the United States under a ten-digit number called a classification (also known as a subheading) and assigns it a tariff rate. ${ }^{34}$ Over 17,000 individual classifications exist. ${ }^{35}$ The HTSUS organizes the classifications into twenty-two sections, divided into ninety-nine chapters, and further divided into numerous headings and subheadings. ${ }^{36}$ Raw goods are found first in the HTSUS, while more highly processed or complex goods are found in later chapters. ${ }^{37}$ The lengthy HTSUS is not codified in the United States Code (U.S.C.) but is instead published by the United States International Trade Commission. ${ }^{38}$

Each ten-digit classification precisely identifies the imported good.

30. Marcos Valadao \& Nara Galeb Porto, MERCOSUR, NAFTA, FTAA and its Effects in Federal Taxation of International Transactions Between the United States and Brazil: A Comparative Study, 10 LAW \& Bus. REV. AM. 705, 715 n.47 (2004).

31. See U.S. InT'L Trade Comm'n, The ECONOMic EFFects of Significant U.S. ImPORT RESTRAINTS xxiii (2007), http://www.usitc.gov/publications/332/pub3906.pdf; BHALA, supra note 21, at 290; Gus Lubin, 25 American Products that Rely on Huge Protective Tariffs to Survive, BUSINESS INSIDER (Sept. 27, 2010, 3:20 PM), http://www.businessinsider.com/americas-biggesttariffs-2010-9.

32. Omnibus Trade and Competitiveness Act of 1988, Pub. L. No. 100-418, 102 Stat. 1107; John W. Head, Global Business: Principles and PRACTICES OF INTERNational COMMERCE AND INVESTMENT 297 n.60 (3d ed. 2012); PAUl H. Vishny, International TRADE FOR the NONSPECIALIST 30 (2d ed. 1997).

33. HEAD, supra note 32, at 297.

34. U.S. Customs, supra note 3 , at 41, 55-57.

35. Harmonized Tariff Schedules, U.S. GOv'T BOOKSTORE, https://bookstore.gpo.gov/catalog/ business-finance/exporting-foreign-trade/harmonized-tariff-schedules (last visited Oct. 3, 2015).

36. U.S. Customs, supra note 3 , at 41.

37. HTSUS, supra note 3; John Brew \& Nicole M. Jenkins, Customs 101: Importation Process Basics, CROwell \& MORING, LLP (Feb. 24, 2010), http://www.crowell.com/documents/customs101-importation-process-basics.pdf.

38. 19 U.S.C. $§ 3007$ (2012). 
The first two digits in a classification derive from the chapter number, which, when the next two digits are added on, form the heading. ${ }^{39}$ For instance, Chapter 4 covers '[d]airy produce; birds' eggs; natural honey; edible products of animal origin, not elsewhere specified or included," and the digits 0406 represent the heading covering "[c]heese and curd." 41 Following the first four digits are two sets of two digit subheadings that further classify the good. ${ }^{42}$ For instance, subheading 0406.10 covers "[f]resh (unripened or uncured) cheese, including whey cheese, and curd," " while subheading 0406.10.64 covers "Swiss or Emmentaler cheese other than with eye formation, Gruyere-process cheese and cheese and substitutes for cheese containing, or processed from, such cheeses." The last two digits further classify the good but are used purely for statistical purposes. ${ }^{45}$

Although the HTSUS contains thousands of different classifications, there are four general ways in which a good may be classified. ${ }^{46}$ First, a good may be classified under a general description-for instance, "accessory" or "container." 47 Second, a good may be classified under an eo nominee provision, which is the commonly used name of the good. ${ }^{48}$ An example of an eo nominee provision is "other wood screws." 49 Third, a good may be classified under a description according to component material-for instance, "[a]rtificial fire logs composed of wax and sawdust, with or without added materials." ${ }^{\circ 0}$ Fourth, a good may be classified under a "description by actual or principal use" example, "implements to be used for agricultural or horticultural purposes." $" 52$

\footnotetext{
39. U.S. Customs, supra note 3 , at 41.

40. HTSUS, supra note 3 , ch. 4.

41. Id. heading 0406 .

42. U.S. CUSTOMS, supra note 3 , at 41.

43. HTSUS, supra note 3, subheading 0406.10.

44. Id. subheading 0406.10.64.

45. U.S. CUSTOMS, supra note 3, at 41-42.

46. BHALA, supra note 21 , at 370 .

47. See Aves. in Leather, Inc. v. United States, 423 F.3d 1326, 1333 (Fed. Cir. 2005); Totes, Inc. v. United States, 69 F.3d 495, 499 (Fed. Cir. 1995).

48. BHALA, supra note 21, at 370.

49. GRK Can., Ltd. v. United States, 761 F.3d 1354, 1356-57 (Fed. Cir. 2014) (quoting

HTSUS, supra note 3, subheading 7318.12.00).

50. HTSUS, supra note 3, subheading 4401.39.20.

51. BHALA, supra note 21, at 370 .

52. Tradewind Farms, Inc. v. United States, 31 Ct. Int'l Trade 664, 665 (2007) (quoting HTSUS, supra note 3, subheading 9817.00.50).
} 


\section{Collection of Tariffs}

There are three main steps to tariff collection: classification, country of origin determination, and valuation. ${ }^{53}$ First, classification is the process of choosing the most appropriate subheading for a good. ${ }^{54}$ Second, the country of origin is the country the good is considered to be "made in"- a potentially difficult task when the good is the product of multiple jurisdictions. ${ }^{55}$ Lastly, valuation is the process of determining the actual value of the good. ${ }^{56}$

The first step, which this Comment focuses on, is classification. As noted, classification is the process of choosing the most appropriate subheading in which to place a good. ${ }^{57}$ Classification is done by choosing the proper chapter, heading, and subheadings, in that order. ${ }^{58}$ Several rules of interpretation aid in the classification of goods, which will be discussed in further detail below. These include the General Rules of Interpretation (GRIs); Additional U.S. Rules of Interpretation; section, chapter and heading notes; and Explanatory Notes. ${ }^{59}$ In addition, the common meaning of words is an important tool in classification. ${ }^{60}$ As the court in Simmon Omega, Inc. v. United States stated: "In the absence of a special commercial designation, the language of a tariff statute is to be construed in accordance with its common meaning." ${ }^{61}$

The second step, country of origin determination, involves a complicated set of rules to determine where the product was made, which need not be discussed here. ${ }^{62}$ Once the determination is made, the correct column in the HTSUS is selected. ${ }^{63}$ The two columns in the HTSUS are Column 1 and Column $2 .^{64}$ Column 1 is divided into General and Special. ${ }^{65}$ Column 1 / General contains the typical tariff rate

\footnotetext{
53. HEAD, supra note 32, at 299.

54. N.Y. Cty. LaWyers' Ass'N, HaNdBook On CUSTOMS \& INTERNATIONAL TRADE LAW 4 (2d ed. 1996)

55. BHALA, supra note 21, at 331-33.

56. HEAD, supra note 32, at 299.

57. N.Y. CTY. LAWYERS' Ass'N, supra note 54, at 4.

58. Avecia, Inc. v. United States, 30 Ct. Int'l Trade 1956, 1973-74 (2006), amended by 31 Ct. Int'l Trade 414 (2007).

59. U.S. CUSTOMS, supra note 3, at 42.

60. Leslie Alan Glick, Guide to United States Customs and Trade Laws: After the Customs ModernizATION ACT 27-28 (3d ed. 2008).

61. 83 Cust. Ct. 14, 20 (1979).

62. HEAD, supra note 32, at 299.

63. Id.

64. See id

65. See id.
} 
applicable to goods imported from the majority of countries. ${ }^{66}$ Column 1 / Special contains lower tariff rates for goods imported from countries that are party to various free trade agreements or that qualify for lower rates because they are less economically developed. ${ }^{67}$ Lastly, Column 2 contains tariff rates at the higher Smoot-Hawley Tariff Act levels for goods imported from restricted countries, currently North Korea and Cuba. $^{68}$

After classifying a good and determining its country of origin, a tariff rate is yielded. ${ }^{69}$ Tariff rates are usually given ad valorem, that is, as a percentage of the value of the imported goods. ${ }^{70}$ However, the rate may also be expressed as a set ratio, called a "specific rate," for instance, 25 cents/kilogram. ${ }^{71}$ In addition, the tariff rate may combine an ad valorem and a specific rate, such as 5\% ad valorem plus 12 cents/kilogram. ${ }^{72}$

The final step in the tariff collection process is valuation, which involves a determination of the value of the imported goods. ${ }^{73}$ The value is based on a good's "actual value," which is typically determined by its transaction value (i.e. what the goods are being bought for). ${ }^{74}$ However, if the stated transaction value is suspect for some reason, other methods may be used, such as the transaction value of identical or similar merchandise, the deductive value, or the computed value. ${ }^{75}$ Deductive value is the resale price minus costs such as general expenses, transportation, taxes, and other various costs. ${ }^{76}$ Meanwhile, the computed value is determined by adding the various costs of producing and shipping the good together. ${ }^{77}$ Once the actual value is determined, the tariff rate is applied to it, resulting in the dollar amount the importer must pay. ${ }^{78}$ The tariffs are then collected by Customs and Border Protection $(\mathrm{CBP}){ }^{79}$

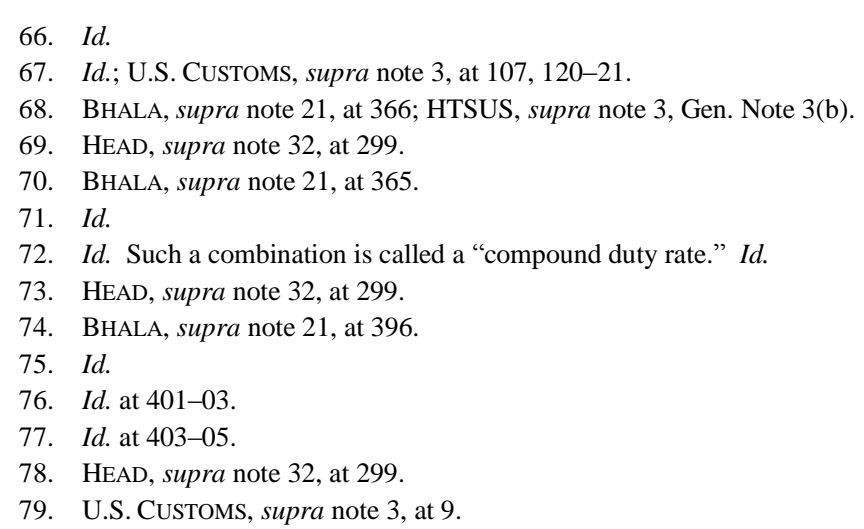




\section{E. Tools for Classifying Goods}

As mentioned, in addition to a word's common meaning, several rules of interpretation accompany the HTSUS to aid in the process of classification. These include the General Rules of Interpretation (GRIs); Additional U.S. Rules of Interpretation; section, chapter and heading notes; and Explanatory Notes. ${ }^{80}$ All of these are legally binding except the Explanatory Notes. ${ }^{81}$

Of the six GRIs, the first four are applied sequentially - that is, the second is applied only if the first does not yield a classification, and so on. ${ }^{82}$ The first GRI states that "classification shall be determined according to the terms of the headings and any relative section or chapter notes and, provided such headings or notes do not otherwise require, according to [the subsequent rules]. ${ }^{, 83}$ The second rule dictates that an unfinished good may be classified as the completed good if it has the "essential character" of the finished good. ${ }^{84}$ In addition, the rule states that a reference to a material or substance includes "mixtures or combinations of that material or substance." goods are classifiable in more than one heading: a) the "most specific description" is preferred; ${ }^{86}$ b) a mixture of different goods is classified as that good which gives the mixture its "essential character"; 87 and c) a good should be classified "under the heading [occurring] last in numerical order." 88 The fourth rule states that goods should be classified with those "to which they are most akin." ${ }^{\text {" }}$ The fifth rule only applies to cases and packing materials, and the sixth rule simply applies the above rules to subheadings. ${ }^{90}$

In addition to the GRIs, the Additional U.S. Rules of Interpretation aid in the process of classification. Two subsections of the first and only rule state:

\footnotetext{
80. Id. at 42 .

81. Maxwell Bioscience, Inc. v. United States, 31 Ct. Int'l Trade 1999, $2004-05$ (2007); U.S. Customs, supra note 3, at 42-44, 53.

82. U.S. Customs, supra note 3 , at 43.

83. HTSUS, supra note 3, Gen. R. Interp. 1.

84. Id. Gen. R. Interp. 2(a).

85. Id. Gen. R. Interp. 2(b).

86. Id. Gen. R. Interp. 3(a). A use provision is generally considered "more specific than an eo nomine provision." U.S. v. Siemens Am., Inc., 653 F.2d 471, 478-79 (C.C.P.A. 1981) (Nies, J., dissenting).

87. HTSUS, supra note 3, Gen. R. Interp. 3(b).

88. Id. Gen. R. Interp. 3(c).

89. Id. Gen. R. Interp. 4.

90. Id. Gen. R. Interp. 5-6; U.S. CUSTOMS, supra note 3, at 43.
} 
In the absence of special language or context which otherwise requires - (a) a tariff classification controlled by use (other than actual use) is to be determined in accordance with the use in the United States at, or immediately prior to, the date of importation, of goods of that class or kind to which the imported goods belong, and the controlling use is the principal use; (b) a tariff classification controlled by the actual use to which the imported goods are put in the United States is satisfied only if such use is intended at the time of importation, the goods are so used and proof thereof is furnished within 3 years after the date the goods are entered .... ${ }^{91}$

Rules 1(c) and 1(d) exist but are irrelevant here. ${ }^{92}$ Lastly, the Explanatory Notes accompanying a tariff subheading, published by the World Customs Organization, help classify goods. ${ }^{93}$ Although these notes are not legally binding, they help clarify the scope of the HTSUS subheadings and offer guidance in their interpretation. ${ }^{94}$

\section{F. Judicial Review of Tariff Classification}

Classification decisions may be appealed administratively and judicially. An importer may challenge a tariff classification administratively by filing a protest with CBP. ${ }^{95}$ In addition, an importer may appeal denied protests to the Court of International Trade (CIT), and in certain situations, may bypass CBP and appeal directly to the CIT. ${ }^{96}$ CBP may also commence actions against importers "to recover customs duties" in the CIT. ${ }^{97}$ The CIT is an Article III court that sits in New York City and has original jurisdiction over a variety of international trade issues, including the classification of imported goods. ${ }^{98}$ Previously, tariff classification appeals were heard by the United States Customs Court (Cust. Ct.), and before, by the Board of General Appraisers. ${ }^{99}$ Appeals of CIT decisions are made to the United States Court of Appeals for the Federal Circuit (Fed. Cir.). ${ }^{100}$ Such appeals were previously made

\footnotetext{
91. HTSUS, supra note 3, Additional U.S. R. Interp. 1(a)-(b).

92. Additional U.S. Rule 1(c) contrasts provisions "for parts of an article" with provisions "for 'parts' or "parts and accessories." Id. Additional U.S. R. Interp. 1(c). Additional U.S. Rule 1(d) relates only to Section XI, covering the mixture of textiles. Id. Additional U.S. R. Interp. 1(d).

93. U.S. Customs, supra note 3 , at 42.

94. BenQ Am. Corp. v. United States, 646 F.3d 1371, 1376 (Fed. Cir. 2011).

95. U.S. CUSTOMS, supra note 3, at 165-66; 19 U.S.C. $\$ 1514(\mathrm{a})(2)$ (2012).

96. U.S. CuSTOMS, supra note 3, at 174-75; 28 U.S.C. $\$ 1581(\mathrm{a})$, (h)-(i).

97. U.S. CUSTOMS, supra note 3, at 175; 28 U.S.C. $§ 1582(3)$.

98. U.S. Customs, supra note 3 , at 172-73.

99. Alberta Gas Chems., Inc. v. United States, 85 Cust. Ct. 122, 125 (1980); GLICK, supra note 60 , at 155 .

100. U.S. CUSTOMS, supra note 3, at 175; 28 U.S.C. $§ 1295(a)(5)$.
} 
to the United States Court of Customs and Patent Appeals (C.C.P.A.), and before, to the Court of Customs Appeals (Ct. Cust.). ${ }^{101}$ A final appeal may be made to the Supreme Court of the United States. ${ }^{102}$

Judicial tariff classification decisions made prior to the adoption of the HTSUS in 1988 are not binding, but may be instructive. ${ }^{103}$ As stated by the legislative history of the HTSUS, "on a case-by-case basis prior decisions should be considered instructive in interpreting the HTS[US], particularly where the nomenclature previously interpreted in those decisions remains unchanged and no dissimilar interpretation is required by the text of the HTS[US]." "104 The word edible is the same word in the HTSUS as in prior tariff classification systems, and the HTSUS does not define the word edible. Thus, prior judicial decisions are helpful in determining the current meaning of the word, though they are not binding.

\section{G. Edible in Tariff Classification}

As noted, the word edible occurs repeatedly in the HTSUS and with significant results. Importantly, whether a good is edible can affect the first step in classification: determining the good's proper chapter. For instance, Chapter 5 covers "[p]roducts of animal origin, not elsewhere specified or included." " Chapter 5 note 1(a) states that, with a few named exceptions, the "chapter does not cover... edible goods." Thus, a basic determination that needs to be made to place a good in Chapter 5 is whether it is edible. The same is true of other chapters as well, including Chapter 7, which covers "[e]dible vegetables and certain roots and tubers," 107 and Chapter 8, which covers "[e]dible fruit and nuts." 108 A case demonstrating the importance of the word edible in determining a good's proper chapter is North American Processing Co.

101. GLICK, supra note 60, at 162-63; U.S. Court of Customs and Patent Appeals (Successor to the Court of Customs Appeals), 1910-1982, FED. JUD. CENTER, http://www.fjc.gov/history/home. nsf/page/courts_special_cpa.html (last visited Oct. 3, 2015).

102. U.S. CUSTOMS, supra note 3, at 176.

103. E.M. Chems. v. United States, 20 Ct. Int'l Trade 382, 386 n.5 (1996). See Franklin v. United States, 289 F.3d 753, 761 (Fed. Cir. 2002) (stating that although a pre-HTSUS case "is not binding precedent on this court, we find its rationale persuasive").

104. H.R. REP. No. 100-576, at 549-50 (1988) (Conf. Rep.), reprinted in 1988 U.S.C.C.A.N. $1547,1582-83$.

105. HTSUS, supra note 3, ch. 5.

106. Id. ch. 5, note 1(a).

107. Id. ch. 7.

108. Id. ch. 8 . 
v. United States. ${ }^{109}$ In this case, the government classified a good consisting of $65 \%$ fat and $35 \%$ beef under subheading 0202.30 .60 of the HTSUS, which covers "meat of bovine animals, frozen, boneless, other." 110 Meanwhile, the importer argued the good should be classified under subheading 1502.00.00, which covers "fats of bovine animals." Chapter 2, under which the government's preferred subheading fell, specifically excludes "[p]roducts... unfit or unsuitable for human consumption."112 The court found "suitable for human consumption" to be synonymous with edible; thus, the good's classification in subheading 1502.00.00 or 0202.30.60 hinged in significant part on whether the good was edible. ${ }^{113}$

The difference the word edible can make in classifying a good is also apparent in Franklin v. United States. ${ }^{114}$ In Franklin, the government classified the good in subheading 2106.90.99, which covers "[f]ood preparations... [o]ther."115 The importer, however, argued the good should be classified under subheading 8421.21.00, which covers "[f]iltering or purifying machinery and apparatus ... [f]or filtering or purifying water." "116 The good was a packet of coral sand used to purify water, arguably a food preparation because residue from the packet was ingested with the purified water. ${ }^{117}$ Whether the sand coral packet was edible was an important issue the court had to decide in classifying the packet because it could only be considered a food preparation if it was edible. $^{118}$

Since the word edible can affect a good's classification, the word can also affect the tariff rate applied to a good. One author rightly notes: "The classification determined by Customs can have a significant effect on the rate of duty applied."119 For example, in North American Processing, the tariff rate of the government's proposed subheading was 4.4 cents $/ \mathrm{kg}$, while the tariff rate of the importer's proposed subheading was significantly less-just .95 cents/kg. ${ }^{120}$ Similarly, in Franklin, the

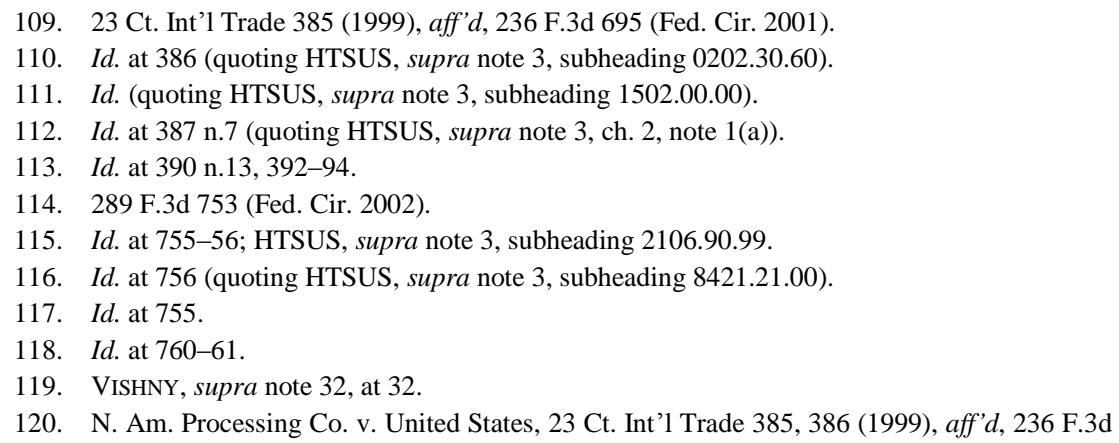


tariff rate of the government's proposed subheading ranged between 8.2\% and $9.4 \%$ ad valorem during the three years the good was being imported. ${ }^{121}$ Meanwhile, the tariff rate of the importer's proposed subheading ranged between $1.6 \%$ and $3.1 \%$ ad valorem during the same time period. ${ }^{122}$ Depending on the shipment, such variations in tariff rate can lead to sizeable differences in the final tariff amount paid by the importer and collected by the government.

\section{ANALYSIS}

As the quote that began this Comment suggests, at first appearance, the definition of the word edible hardly seems to warrant elaborationsomething is edible if it can be eaten. ${ }^{123}$ Indeed, the word's etymology suggests such a definition. Edible derives from the Latin word edibilis, meaning "eatable." 124 However, as this Comment discusses, applying this simple definition creates several problems. Thus, courts have turned to, and parties have argued for, various other tests to determine whether a good is edible. Such tests include: (1) whether the good appears edible to the senses, ${ }^{125}$ (2) whether the good provides nourishment, ${ }^{126}$ (3) whether the good's constituent parts are edible, ${ }^{127}$ (4) whether the good is principally used as food, ${ }^{128}(5)$ whether the good may be eaten without harmful effects, ${ }^{129}$ (6) whether the good is "habitually eaten," ${ }^{130}$ and (7) whether the good is actually eaten. ${ }^{131}$ This Comment argues that a good should be considered edible if it can be eaten without harmful effects, but that whether the good is "habitually eaten" should control if testing the good is dangerous, and that if neither of these tests yields a result, the matter should be resolved by whether the good is actually eaten. This is the clearest and simplest definition that accords most closely to the common meaning of edible.

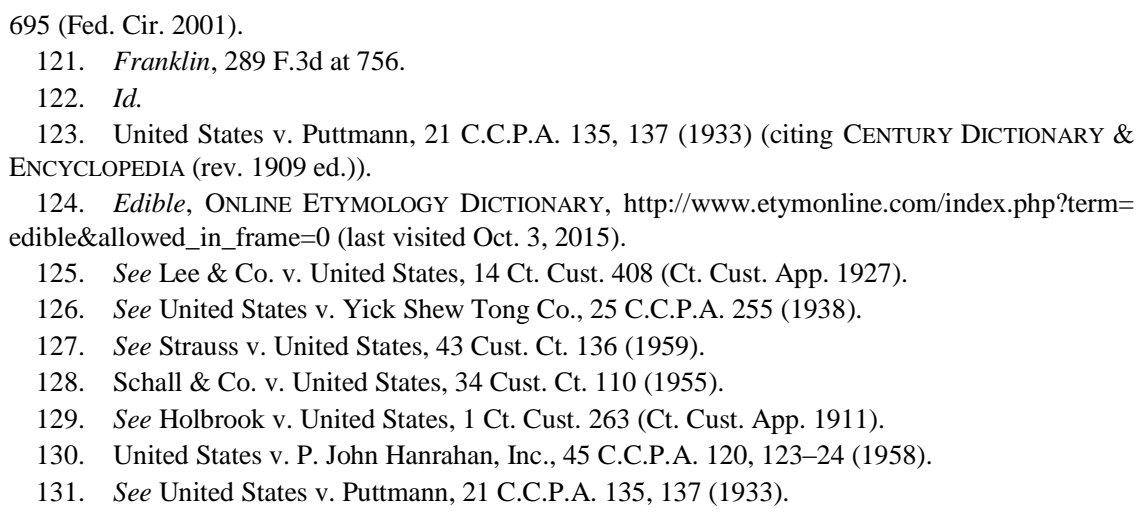




\section{A. Tests That Should Not Be Used}

1. Edible as Eatable

As noted, one obvious test for whether a good is edible is whether it can be eaten. Somewhat surprisingly, however, courts rarely apply this definition. Although rare, one clear example occurs in the dissent in United States v. P. John Hanrahan, Inc. ${ }^{132}$ The dissenting judge argued that the good in question, wheat gum gluten, was inedible, in large part because "if chewed, [it] becomes a spongy mass which is virtually impossible to swallow-and even should it be swallowed, is indigestable."133 Another example occurs in Drygel, Inc. v. United States, ${ }^{134}$ where the court concluded that Gel-A-Mint MagikStrips"thin, sugar-free breath strips"135 — were edible because they were "ingested and consumed." "136

However, whether a good can be eaten should not determine whether the good is edible. Principally, defining edible as eatable would include obviously inedible goods such as poisonous or rotten foods because they may physically be consumed. Although outrageous, such a definition could also potentially allow an object such as a plane to be considered edible. ${ }^{137}$ Since the range of products that can be eaten - that is, chewed and swallowed - is so vast, this definition would drain the word edible of meaning. The word would effectively cease to differentiate edible goods from their inedible counterparts. Thus, whether a good can be eaten should not determine whether it is considered edible.

\section{Edible Based on the Senses}

A factor some courts have used to determine whether a good is edible is whether it appears edible to the senses, including sight, smell, and taste. For instance, Holbrook v. United States featured a dispute as to whether olive oil imported by several different companies should be classified under paragraph 40 of the Tariff Act of 1897, as the government argued, or paragraph 626 , as the importers argued. ${ }^{138}$

\footnotetext{
132. See P. John Hanrahan, 45 C.C.P.A. at 120.

133. Id. at 125 (Worley, J., dissenting).

134. 31 Ct. Int'l Trade 1319 (2007), rev'd on other grounds, 541 F.3d 1129 (Fed. Cir. 2008).

135. Id. at 1320 .

136. Id. at 1329.

137. See Michel Lotito, supra note 2 .

138. 1 Ct. Cust. 263, 264 (Ct. Cust. App. 1911).
} 
Paragraph 40 covered "[o]live oil, not specially provided for in this act," while paragraph 626 covered "olive oil for manufacturing or mechanical purposes fit only for such use." 139 Whether the olive oil was edible was the key determination in classifying the olive oil. ${ }^{140}$ In reaching its decision, the court considered a wide variety of evidence on the taste and smell of the olive oil. ${ }^{141}$ For instance, witnesses for the importers testified that the olive oil was "rancid," had an "acrid, unpleasant taste," and was "very bitter." 142 Against this testimony, the court weighed a government witness's findings, noting:

[A]s to seven samples, he found them to be slightly resinous or detected a slight resinous-like aftertaste, and, as to three others, he reported that their taste was a little off or that they were not good tasting, but these unfavorable conditions were not sufficient, in his opinion, to render such samples unfit for food.

In addition, other government witnesses testified that they had not discovered any rancidity in the olive oil either. ${ }^{144}$

Other courts too have relied at least in part on the appearance, smell, or taste of a good to determine whether it is edible. For instance, in Lee \& Co. v. United States, the court itself tasted the goods and relied in large part on the fact that "[t]he samples in evidence have a sweetish flavor with a slight tang" to conclude that several dried Chinese fruits could not be classified as "inedible drug[s]." ${ }^{\text {145 }}$ In addition, the court in United States $v$. Puttmann noted, though did not seem to rely as heavily on, the fact that soups and jellies made from the gelatin in question were reported as having a "very fine" taste. ${ }^{146}$

Furthermore, in a couple instances, the Explanatory Notes focus on the appearance, smell, and taste of a good to determine whether it is edible. For instance, the Explanatory Note to heading 1503 states that "[o]leo-oil (edible) is a white or yellowish solid fat of soft consistency with a faint smell of tallow and an agreeable flavor."147 On the contrary, "[t]allow oil (inedible oleo-oil) is a yellowish liquid, smells of tallow,

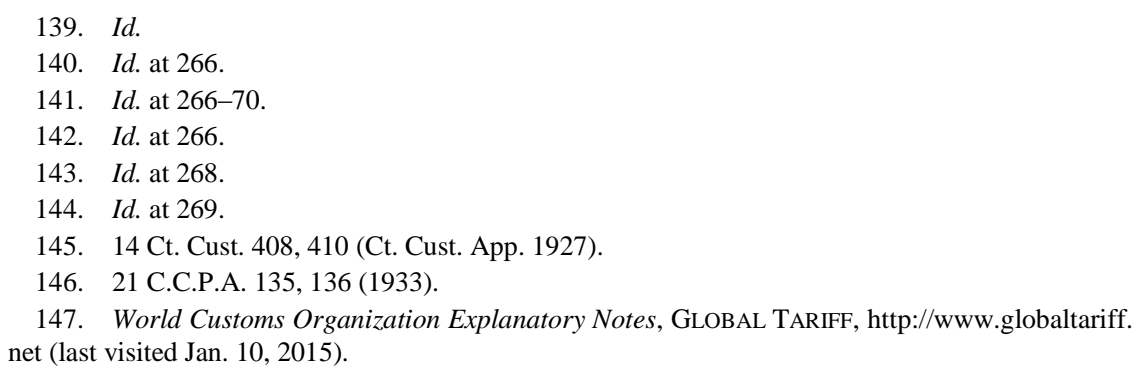


and turns rancid very easily when exposed to air." 148

Despite their use in some cases and limited parts of the Explanatory Notes, a good's appearance, smell, and taste should not be used to determine whether the good is edible. First, this test is too subjective. From common experience, we know that different individuals and cultures have widely different tolerances when it comes to the appearance, smell, and taste of food. What tastes like a delicacy to certain people or cultures can be revolting to others. ${ }^{149}$ Thus, people's basic inability to agree on what exactly a good actually smells or tastes like presents an initial hurdle for this test. Second, setting a line for how "bad" a good would have to look, smell, or taste before being considered inedible would be difficult. There is no bright line for when a good no longer tastes or smells edible. Third, a good's appearance to the senses does not necessarily align with whether the good is edible. For instance, Limburger cheese is popularly known for its off-putting smell, yet is still widely recognized as edible. ${ }^{150}$ The same is true of a Southeast Asian fruit called a durian, which people widely eat despite its terrible smell. ${ }^{151}$ Granted, in the few situations where the Explanatory Notes describes what an edible or inedible good is like, taking the appearance, smell, or taste of a good into account may be of some use. However, these situations are unsurprisingly rare, as it would be unrealistic for the Explanatory Notes' authors to describe the physical nature of every single edible good. Thus, unless given in the Explanatory Notes, a good's appearance, smell, or taste should not affect whether the good is considered edible.

\section{Edible as Providing Nourishment}

Another factor courts have used to determine whether a good is edible is whether it provides nourishment. For instance, in Strauss $v$. United States, the court considered testimony that sugar in bubble gum, the good in question, could provide "sucrose sufficient to the needs of one's health" if only "enough gum were chewed." 152 Based on this

\footnotetext{
148. Id.

149. See Beth Greenfield, 15 Insects You Won't Believe Are Edible, NBC News (Oct. 27, 2011 10:39:56 AM), http://www.nbcnews.com/id/45048564/ns/travel-travel_tips/t/insects-you-wontbelieve-are-edible/.

150. Limburger, CHEESE.COM, http://www.cheese.com/limburger/ (last visited Oct. 3, 2015).

151. Henry Genthe, Durians Smell Awful-But the Taste Is Heavenly, SMITHSOnian Mag. (Sept. 1999), http://www.smithsonianmag.com/science-nature/durians-smell-awful-but-the-taste-isheavenly-57313254/?no-ist.

152. 43 Cust. Ct. 136, 139 (1959).
} 
testimony, the court concluded the component parts of bubble gumsugar and dextrose - are edible because they are "nutritious when swallowed." ${ }^{\prime 53}$ Although the court in Strauss ultimately held that bubble gum itself was inedible, its conclusions on sugar and dextrose suggest a willingness to define a good as edible if it provides nutrition. Another example of such willingness occurred in United States v. Yick Shew Tong Co. ${ }^{154}$ In this case, the court considered evidence provided by a chemistry professor at the University of California on the "nutritive value" of various Chinese plants in question. ${ }^{155}$ Specifically, the court examined "with much interest and care" a pamphlet by the professor analyzing the food value of the goods. ${ }^{156}$

Whether a good provides nutrition should not be a factor in determining whether a good is edible. First, such a definition is overinclusive because it includes goods that are clearly not edible. For instance, such a definition would include poisonous berries or rotting meat because these goods still have caloric content, vitamins, protein, etc. ${ }^{157}$ Second, using this test may exclude obviously edible goods, such as celery or cucumber, which take more calories to consume than they possess. ${ }^{158}$ Lastly, this test introduces an unnecessary level of complexity. Several courts using this test examined lengthy, complex testimony on the chemical analysis of goods to determine their nutritive value, or lack thereof. ${ }^{159}$ Considering that a good's nutritive value is not an accurate predictor of whether it is edible, such examination is a waste of both the expert and the court's time. Thus, whether a good provides nutrition should not be used to determine whether the good is edible.

\footnotetext{
153. Id. at 140 .

154. 25 C.C.P.A. 255 (1938).

155. Id. at 265 .

156. Id.

157. Rachel Frost, Does Drought Contribute to Livestock Losses from Poisonous Plants?, U. OF IDAHO, http://www.webpages.uidaho.edu/range556/appl_behave/projects/drought.html (last visited Oct. 3, 2015) (stating that "many poisonous plants are quite nutritious"). See also UW Food Irradiation Educ. Grp., The Facts: What is Food Irradiation?, U. OF WIS., http://uw-foodirradiation.engr.wisc.edu/Facts.html (last visited Oct. 3, 2015) (noting that a food's nutritional content remains intact after irradiation, which is a process used to make inedible foods containing dangerous microbes edible).

158. Mike Adams, The Top Five Negative-Calorie Health Foods That Burn Fat While Making You Feel Full, NAT. NEWS (Jan. 4, 2011), http://www.naturalnews.com/030912_negativecalorie_foods_burn_fat.html\#.
}

159. See, e.g., Strauss v. United States, 43 Cust. Ct. 136, 137-39 (1959). 


\section{Edible as Edible Constituent Parts}

Another factor that parties have argued for, but courts have not used, is whether a good's constituent parts are edible. For instance, the government put forth this argument in defending its classification of bubble gum in Strauss. ${ }^{160}$ In Strauss, the government argued that bubble gum was "an edible preparation for human consumption" and thus dutiable at $20 \%$ ad valorem, while the importer argued it was not and thus dutiable at $10 \%$ ad valorem. ${ }^{161}$ The government argued bubble gum was edible because "the preparation bubble gum contains as components sugar and dextrose syrup which are swallowed in the masticatory process."162 Likewise, in Franklin, the government argued that waterpurifying sand coral packets were edible because "the elements imparted by the product are ultimately ingested by the consumer," creatively suggesting that "hardness and alkalinity" were the ingested elements. ${ }^{163}$

However, courts have properly rejected this argument, and whether a good's constituent parts are edible should not determine whether the good is edible. Principally, the edibility of a good's constituent parts is irrelevant because the good itself is the object being classified, not the constituent parts. ${ }^{164}$ This was the court's reasoning in Strauss. There, in concluding that bubble gum was not an "edible preparation," the court reasoned:

The common meaning to be applied is that of the imported preparation, not of its several components. While the sugars and syrup in the preparation "bubble gum" are nutritious when swallowed, and in that sense they (the sugars and syrup) are edible, there is no such evidence as to the preparation "bubble gum." To the contrary, it appears that bubble gum is not customarily eaten and swallowed. ${ }^{1}$

In turn, the court in Franklin relied on Strauss in reaching its conclusion that the sand coral packets in question were inedible: "Similarly, nothing in the instant record indicates that one would eat one of Franklin's one-gram bags of coral sand. Even if the goods' component parts, namely calcium carbonate or, as the government argues, alkalinity, are ingested, this is not enough to bring Franklin's

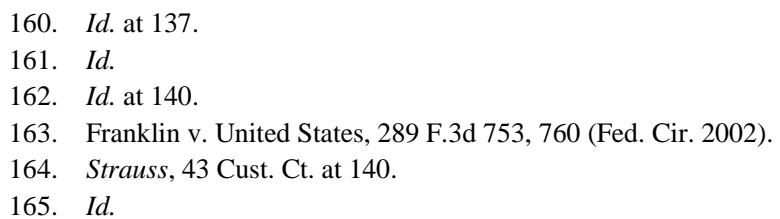


product within heading 2106."166 Thus, the constituent parts test should not be used because it puts the focus of the classification analysis in the wrong place.

\section{Edible Based on Principal Use}

A final factor to determine whether a good is edible, which parties have argued for but courts have correctly rejected, is whether the good is principally used for food. Principal use will be discussed further in Part III.B in connection with the Additional U.S. Rules. Here, however, it is discussed solely with regard to its usefulness in determining whether a good is edible. One case discussing principal use is Schall \& Co. $v$. United States, where the importer argued that angelica glace, a flattened plant stalk, should be deemed inedible because its principal use was as a cake decoration rather than as food. ${ }^{167}$ The court properly rejected this argument, however, and stated: "While it may be used because of its eye appeal as a decoration, it is eaten as part of an article of food. Many foods are prepared so as to have a pleasing appearance, but they are still foods and are consumed as such." 168

The principal use test should be rejected for a couple of reasons. First and foremost, the nature of a good is not changed by its principal use. For example, though the gelatin at issue in Puttmann was principally used for making photographic equipment, it could still be safely consumed, and was actually used in making soups and jellies. ${ }^{169}$ Principal use does not affect the reality of whether a good is edible. In addition, as will be discussed, courts must look at many factors to determine a good's principal use. Such analysis, though useful in various contexts, is a sap on judicial resources in determining whether a product is edible. Thus, the inquiry into whether a good is edible should not focus on its principal use.

\section{B. Tests That Should Be Used}

A good should be considered edible if it can be eaten without harmful effects. However, if testing the good is dangerous, whether the

\footnotetext{
166. Franklin, 289 F.3d at 761.

167. 34 Cust. Ct. 110, 112 (1955) ("Plaintiff concedes that the merchandise can be eaten without deleterious effect, but claims that this fact does not make it an edible preparation for human consumption on the ground that its use is as a decorative item and not as food ....").

168. Id. at 114 .

169. United States v. Puttmann, 21 C.C.P.A. 135, 136 (1933).
} 
good is "habitually eaten" should dictate whether it is edible. Finally, if neither of these tests yields a result, the matter should be resolved by whether the good is actually eaten. This is the clearest and simplest definition that accords most closely to the common meaning of edible.

\section{Edible as Eatable Without Harmful Effects}

The first test courts should use to determine whether a good is edible is whether it may be eaten without harmful effects. This test was explicitly used in Schall \& Co., where the court concluded that angelica glace was edible and explained: "In the instant case, the evidence establishes that angelica glace can be eaten without deleterious effects . ..."170 In addition, the court in Holbrook essentially used this test. The Holbrook court concluded that a particular shipment of olive oil was inedible, in part, because of testimony like that of a Mr. Snevily, who tasted the oil and testified that it "nauseated him" and gave him "gas for several hours after taking it."

\section{a. Benefits of the Harmful Effects Test}

This test, whether a good can be eaten without harmful effects, should be used for at least two main reasons. First, besides eatable, it is closest to the common meaning of edible. Common meaning may be determined by a court's "own understanding, dictionaries and other reliable sources." 172 Dictionary definitions especially play an important role in the case law, with many of the cases cited in this Comment quoting a dictionary definition of edible to help determine its meaning. ${ }^{173}$ In most of these dictionary definitions, the phrase fit to be eaten appears. For instance, in P. John Hanrahan, the court noted that Webster's New International Dictionary defined edible as "[f]it to be eaten as food; eatable; esculent; as edible fishes." ${ }^{174}$ In addition, in Yick Shew Tong, the court quoted the Century Dictionary and Encyclopedia, which defines edible as "[e]atable; fit to be eaten as food; esculent; specifically applied

170. Schall \& Co., 34 Cust. Ct. at 114 .

171. Holbrook v. United States, 1 Ct. Cust. 263, 266 (Ct. Cust. App. 1911).

172. N. Am. Processing Co. v. United States, 23 Ct. Int'l Trade 385, 390 (1999) (quoting Medline Indus., Inc. v. United States, 62 F.3d 1407, 1409 (Fed. Cir. 1995)), aff'd, 236 F.3d 695 (Fed. Cir. 2001).

173. United States v. P. John Hanrahan, Inc., 45 C.C.P.A. 120, 122-23 (1958); Schall \& Co., 34 Cust. Ct. at 113; United States v. Yick Shew Tong Co., 25 C.C.P.A. 255, 268 (1938).

174. P. John Hanrahan, Inc., 45 C.C.P.A. at 122-23 (quoting WEBSTER's NeW INTERNATIONAL DICTIONARY (1932 ed.)). 
to objects which are habitually eaten by man, or specifically fit to be eaten, among similar things not fit for eating...."175 The MerriamWebster Dictionary currently defines edible as "fit to be eaten." 176 If a good is "fit to be eaten," it strongly implies that the good may be eaten without harmful effects. It is hard to imagine that a good could be fit to be eaten but cause harmful effects, or that a good could be eaten without harmful effects but not be fit to be eaten. Thus, the dictionary definition of edible, and in turn the common meaning of edible, supports the harmful effects test. This matters because "absent contrary definitions in the HTSUS or legislative history, the terms used in the headings and subheadings are to be construed according to their 'common and popular meaning.," 177

Second, the harmful effects test should be used because, unlike the "eatable" test, it excludes obviously inedible goods and provides an effective means for differentiating between goods. Thus, this test would exclude poisonous or rotten foods because they cannot be eaten without harmful effects. In addition, unlike the "eatable" test, the harmful effects test actually yields different classifications. For instance, the Holbrook court classified the olive oil in question as inedible because, though it could be physically swallowed, it caused harmful effects. ${ }^{178}$ Since the harmful effects test is more effective than the "eatable" test and because, besides "eatable," it most closely resembles the common meaning of edible, whether a good is edible should first be determined by whether it can be eaten without harmful effects.

\section{b. Problems with the Harmful Effects Test}

Although the harmful effects test is the most effective test that accords most closely to the common meaning of edible, several issues plague its use. First, it is unclear what exactly a harmful effect is. Second, how much of a good must be consumed to carry out the test? Third, and perhaps most importantly, there are serious questions as to how to practically carry out this test without subjecting individuals to harm.

175. Yick Shew Tong Co., 25 C.C.P.A. at 268 (quoting CEnTURY Dictionary AND ENCYCLOPEDIA).

176. Edible, MERRIAM-WEBSTER, http://www.merriam-webster.com/dictionary/edible (last visited Oct. 3, 2015).

177. Avecia, Inc. v. United States, 30 Ct. Int'l Trade 1956, 1974 (2006), amended by 31 Ct. Int'l Trade 414 (2007).

178. See Holbrook v. United States, 1 Ct. Cust. 263, 266, 269-70 (Ct. Cust. App. 1911). 
The meaning of harmful effect is uncertain in at least a couple senses. First, it is unclear how harmful the harm must be. For instance, in Holbrook, the court noted that Mr. Snively had "gas for several hours after taking it." ${ }^{\prime 19}$ However, many goods produce gas or similar mild effects if consumed, so such a low threshold for harmful effect would unnecessarily exclude many goods commonly considered edible. Probably, more what is meant by harmful effect is the nauseous feeling that Mr. Snively experienced for several hours, or of course, even more serious side effects that may come from eating poisonous or rotten goods. Second, many goods may result in long-term harmful effects if consumed, yet are commonly considered edible-for instance, "junk food" such as soda and potato chips. In addition, testing the long-term effects of goods "at the moment of importation," which is when goods are classified, is impractical. Harmful effect, then, should be construed to mean one that occurs in the short-term, such as a few days. Thus, although a rough guide, harmful effect should refer only to serious, shortterm harms.

A second problem is how much of a good must be consumed in testing for harmful effects. This issue was noted by the court in Yick Shew Tong, which concluded that the goods in question were inedible even though evidence suggested they could be consumed without harmful effects, in part because "[m]any articles ... can be eaten in moderation without deleterious results." 180 This problem can be resolved by requiring a certain minimum amount of a good to be consumed before observing for harmful effects. Such a requirement could be a "serving size" of the good - a fairly objective amount that should allow the issue noted in Yick Shew Tong to be avoided.

One last and extremely significant problem with the harmful effects test is how to determine whether a good can be eaten without harmful effects. If there is doubt as to whether the good produces harmful effects when eaten, it is unlikely many people will be willing to consume the good. Nor should they. A policy requiring human life or health to be jeopardized simply to determine a good's proper tariff classification is hardly justifiable. Granted, in several cases, customs examiners and even judges have voluntarily tested imported goods. ${ }^{181}$ If people are willing to try the good, this problem may be eliminated. However, this will not necessarily be the case, especially if significant questions exist

179. Id. at 266 .

180. Yick Shew Tong Co., 25 C.C.P.A. at 267-68.

181. See, e.g., Schall \& Co. v. United States, 34 Cust. Ct. 110, 111 (1955). 
as to the safety of consuming a good. Thus, although the harmful effects test is an effective test that adheres closely to the common meaning of edible, safety concerns may limit its application.

\section{Edible as Habitually Eaten}

If nobody is willing to try a good to determine whether it can be eaten without harmful effects, a proxy factor should be used-namely, whether the good is habitually eaten. This test is widely cited in the case law. Indeed, according to North American Processing, the habitually eaten test is the test in the case law for whether a good is edible. ${ }^{182}$ For instance, in Yick Shew Tong, the court held the Chinese plants in question to be inedible because "there [was] no showing that there was any habitual use of them for food purposes by any one." 183 In Strauss, the court concluded that bubble gum was inedible because it was "not customarily eaten and swallowed." 184 In addition, in Schall \& Co., the court concluded that angelica glace was edible, in part, because it was "eaten habitually as part of the cake which it garnishes."185 Also, in $P$. John Hanrahan, the court held that wheat gum was edible because it was "habitually eaten as an ingredient of such foods as bread.". 186

In addition to its prevalence in case law, the habitually eaten test is found in at least a couple dictionary definitions of edible. In Yick Shew Tong and Schall \& Co., for instance, the courts quoted the Century Dictionary and Encyclopedia, which defined edible as, in part, "objects which are habitually eaten by man." ${ }^{\text {"187 }}$ As noted, this is important because dictionary definitions can inform courts of the common meaning of HTSUS terms.

Furthermore, the habitually eaten test allows courts to safely determine whether a good can be eaten without harmful effects. No potentially dangerous experimentation is needed to determine whether a

182. N. Am. Processing Co. v. United States, 23 Ct. Int'1 Trade 385, 390 \& n.13 (1999) (stating that "[c]ase law finds a product is suitable for human consumption when the product is habitually eaten as an ingredient in food, even though the product may not be eaten by itself at importation" and that "suitable for human consumption" is synonymous with edible), aff'd, 236 F.3d 695 (Fed. Cir. 2001).

183. Yick Shew Tong Co., 25 C.C.P.A. at 265-66.

184. Strauss v. United States, 43 Cust. Ct. 136, 140 (1959) ("There is not a shred of evidence before us that the preparation bubble gum is ever eaten ....").

185. Schall \& Co., 34 Cust. Ct. at 114 .

186. United States v. P. John Hanrahan, Inc., 45 C.C.P.A. 120, 124 (1958).

187. Yick Shew Tong Co., 25 C.C.P.A. at 268 (quoting CENTURY DiCTIONARY AND ENCYClOPEDIA); Schall \& Co., 34 Cust. Ct. at 113 (quoting Yick Shew Tong Co., 25 C.C.P.A. at 267-68 (quoting CENTURY DiCTIONARY AND ENCYCLOPEDIA)). 
good is habitually eaten. In addition, if a good is habitually eaten, it stands to reason that it does not cause any significant harmful effects; otherwise, people would have stopped eating it long ago. The universe of goods within the category habitually eaten is completely contained within the category of goods that can be eaten without harmful effects. Because determining whether a good is in the latter category may be unsafe at times, the former category can be used as a proxy to determine whether a good is edible. However, if sufficient evidence is introduced that establishes a good can be eaten without harmful effects, it should automatically be considered edible, even if the good is not habitually eaten.

Though useful as a proxy, the habitually eaten test is not without problems. Most obviously, what does habitual mean? Although many cases use this phrase, courts do not precisely define the term. One thing the case law does make clear, though, is that "habitual" use excludes "exceptional" use. ${ }^{188}$ For example, the Strauss court held that bubble gum was inedible because it is not customarily swallowed, even though bubble gum is sometimes inadvertently swallowed. ${ }^{189}$ The Yick Shew Tong court stated this principle explicitly, declaring that "exceptional or incidental use does not control classification." ${ }^{190}$ Thus, in Yick Shew Tong, the court concluded the Chinese plants were not habitually eaten because the only time they had been eaten as food was a few days before the trial by witnesses and once by a doctor in the course of experiments. ${ }^{191}$ Thus, a good should not be considered habitually eaten if it is only inadvertently consumed or if there are extremely few recorded instances of it being eaten.

However, the floor for habitual should not be much higher than a few instances of people intentionally consuming the good. Oftentimes, the good in question is a foreign good, consumed only by a relatively small immigrant population. ${ }^{192}$ That a good is eaten by only a small number of people does not take away from the fact that it a fortiori may be eaten without harmful effects. In addition, the test for edible should not be subject to implicit anti-foreign bias, as it would be if a good must

\footnotetext{
188. Yick Shew Tong Co., 25 C.C.P.A. at 267-68.

189. Strauss, 43 Cust. Ct. at 140.

190. Yick Shew Tong Co., 25 C.C.P.A. at 267.

191. Id. at 264-66.

192. See id. at 263-64 (discussing whether a good used regularly only by "the Chinese portion of the country's population" is edible). See also Lee \& Co. v. United States, 14 Ct. Cust. 408, 40910 (Ct. Cust. App. 1927) (discussing whether a good "common among the Chinese people" is edible).
} 
be consumed by mainstream America to be considered habitually eaten.

Another problem facing the habitually eaten test is how to determine whether newly created goods are edible. For instance, in Barad Shaff Sales Co. v. United States, the court considered the classification of Junex, an invented good composed of butterfat and sugar, used as an ingredient in ice cream. ${ }^{193}$ The problem in such a situation is that no established habit exists by which to determine whether the good is habitually eaten. In some situations, the initial test of whether a good can be eaten without harmful effects may afford an answer. Thus, for instance, in Barad Shaff, a sample of the butterfat and sugar mix very likely could have been safely consumed to test for harmful effects. However, in other situations, whether the new good can be eaten without harmful effects may be uncertain enough to warrant against consuming it. In addition, even if the ingredients of a good are known to be safe, consuming the good itself may present health risks. For example, had bubble gum been a newly created good when it was examined in Strauss, consuming the bubble gum would have been ill-advised because of the choking risk, even though its ingredients were edible. In either situation, neither the harmful effects test nor the habitually eaten test will provide an answer for whether a good is edible.

\section{Edible as Actually Eaten}

If neither the harmful effects test nor the habitually eaten test can answer whether a good is edible, the good should be considered edible if it is actually eaten. The idea that a good should be considered edible if actually eaten has support in several sources. For instance, this was the importer's argument and court's conclusion in Puttmann. ${ }^{194}$ There, gelatin was originally imported for use in making photographic film and was labeled "for technical purposes." "195 The government relied on this fact to argue that the gelatin should be classified as "gelatin not specially provided for" rather than "edible gelatin." 196 However, there was also evidence "that a portion of the importation was turned over to a chef of a New York hotel and by him used to make 'desserts, soup, jelly, and all sorts of aspic'; that its taste was 'very fine' and that it was served to guests at the hotel."197 Mainly because the good was actually eaten, the

193. 56 Cust. Ct. 447, 447-48 (1966).

194. United States v. Puttmann, 21 C.C.P.A. 135, 136-37 (1933).

195. Id. at 136-38.

196. Id. at 137 .

197. Id. at 136 . 
court concluded that the gelatin was "edible gelatin" rather than "gelatin not specially provided for." 198

\section{a. Additional U.S. Rules of Interpretation}

One issue the actually eaten test raises is whether Additional U.S. Rules 1(a) and (b) apply to tariff classifications that use the word edible. Additional U.S. Rule 1(a) states:

In the absence of special language or context which otherwise requires - (a) a tariff classification controlled by use (other than actual use) is to be determined in accordance with the use in the United States at, or immediately prior to, the date of importation, of goods of that class or kind to which the imported goods belong, and the controlling use is the principal use ....

As a threshold matter for Additional U.S. Rule 1(a) to apply, the tariff classification must be controlled by "principal use" rather than "actual use."200 " Principal use' is defined as the use "which exceeds any other single use." 201 Once the tariff classification is determined to be governed by principal use, courts look to various factors, sometimes referred to as Carborundum factors, to determine what "class or kind" of good an imported good belongs to. ${ }^{202}$ According to Lenox Collections $v$. United States:

These factors may include: (1) the general physical characteristics of the merchandise; (2) the expectation of the ultimate purchasers; (3) the channels of trade in which the merchandise moves; (4) the environment of the sale (e.g. the manner in which the merchandise is advertised and displayed); and (5) the usage of the merchandise. ${ }^{203}$

Meanwhile, Additional U.S. Rule 1(b) applies when the tariff classification is controlled by actual use. As a threshold matter for Additional U.S. Rule 1(b) to apply, the tariff classification must be

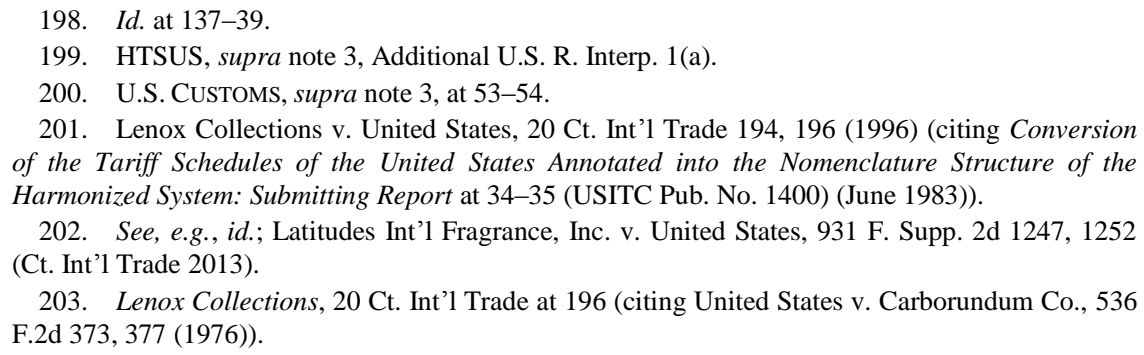

202. See, e.g., id.; Latitudes Int'l Fragrance, Inc. v. United States, 931 F. Supp. 2d 1247, 1252 (Ct. Int'l Trade 2013).

203. Lenox Collections, 20 Ct. Int'l Trade at 196 (citing United States v. Carborundum Co., 536 F.2d 373, 377 (1976)). 
controlled by actual use. ${ }^{204}$ If the tariff classification is controlled by actual use, the importer must follow three requirements to classify the good in the actual use classification: "[1] such use is intended at the time of importation, [2] the goods are so used and [3] proof thereof is furnished within 3 years after the date the goods are entered." 205 In satisfying the third requirement, the importer must maintain detailed records as to how the goods are used upon importation. ${ }^{206}$

As noted, whether a classification is controlled by principal or actual use dictates whether Additional U.S. Rules 1(a) or (b) apply. Recall that a good may be classified in one of four different classification types: "(1) a general description; (2) an eo nominee description... ; (3) a description according to component material; or (4) a description by actual or principal use." 207 The question, then, is whether a classification using the word edible is controlled by principal or actual use, and thus subject to the various requirements outlined above. As an initial matter, a heading or subheading with the word edible will not be a general description classification, which includes broad classifications such as "accessory" or "container." 208 Nor will a heading or subheading with the word edible be a provision according to component material, which includes classifications such as "[a]rtificial fire logs composed of wax and sawdust, with or without added materials." 209

A heading or subheading is considered an eo nominee classification if it "describes an article by a specific name." 110 Examples of eo nominee provisions include "self-tapping screws,"211 "compound optical microscopes," 212 "travel, sports and similar bags,",213 and subheadings as complex as "[o]ther vegetables prepared or preserved otherwise than by vinegar or acetic acid, frozen, other than products of heading 2006."

\footnotetext{
204. U.S. CUSTOMS, supra note 3, at 54.

205. HTSUS, supra note 3, Additional U.S. R. Interp. 1(b). See 19 C.F.R. § 10.133 (2015).

206. U.S. CUSTOMS, supra note 3, at 54; 19 C.F.R. § 10.137(a) (2015).

207. BHALA, supra note 21, at 370 .

208. See Aves. in Leather, Inc. v. United States, 423 F.3d 1326, 1333 (Fed. Cir. 2005); Totes, Inc. v. United States, 69 F.3d 495, 499 (Fed. Cir. 1995).

209. HTSUS, supra note 3, subheading 4401.39.2000 (emphasis added).

210. CamelBak Prods., LLC v. United States, 649 F.3d 1361, 1364 (Fed. Cir. 2011).

211. GRK Can., Ltd. v. United States, 761 F.3d 1354, 1357-58 (Fed. Cir. 2014) (quoting HTSUS, supra note 3, subheading 7318.14.10).

212. Carl Zeiss, Inc. v. United States, 195 F.3d 1375, 1380-81 (Fed. Cir. 1999) (quoting HTSUS, supra note 3, heading 9011).

213. CamelBak Prods., 649 F.3d at 1367-68 (quoting HTSUS, supra note 3, subheading 4202.92).

214. R.T. Foods, Inc. v. United States, 757 F.3d 1349, 1353-54 (Fed. Cir. 2014) (quoting HTSUS, supra note 3 , heading 2004).
} 
Meanwhile, principal or actual use provisions "classify commodities by use." 15 Principal or actual use provisions often contain some form of the word use. $^{216}$ For example, "lighting sets of a kind used for Christmas trees," 217 "[g]lassware of a kind used for table, kitchen, toilet, office, indoor decoration or similar purposes," 218 and "implements to be used for agricultural or horticultural purposes" are all use provisions. ${ }^{219}$ However, a heading or subheading may be a use provision even if it does not contain the word use. ${ }^{20}$ For instance, the court in Stewart-Warner Corp. v. United States held that "bicycle speedometers" was a use provision "because the noun 'bicycle' acts as an adjective modifying 'speedometer' in a way that implies use of the speedometer on a bicycle." 221 The court went on to say: "If the modifying word or words were purely descriptive-i.e., a 'green' speedometer or a 'three-inch-indiameter' speedometer - then the question of use would not arise. However, by employing the term 'bicycle' to modify 'speedometer,' logic compels one to consider some aspect of use." $" 222$

Although no case has decided the issue, a heading or subheading containing the word edible should generally be considered an eo nominee provision. First of all, headings and subheadings containing the word edible generally do not contain the word use - the typical indicator of a use provision. Instead, classifications with the word edible include phrases such as "ice cream and other edible ice," "223 "edible products of animal origin, not elsewhere specified or included," 224 and "[m]eat and edible offal, of the poultry of heading 0105 , fresh, chilled or frozen.",225

The question, then, is whether the adjective edible is "purely descriptive," as eo nominee provisions are, or implies a use. ${ }^{226}$ If edible implies a use, then determining whether a good is edible will require

215. Clarendon Mktg., Inc. v. United States, 144 F.3d 1464, 1467 (Fed. Cir. 1998).

216. See Tradewind Farms, Inc. v. United States, 31 Ct. Int'1 Trade 664, 667 (2007) ("Plaintiff's proposed HTSUS subheading is an actual use provision, as it contains the phrase "to be used for.").

217. Primal Lite, Inc. v. United States, 182 F.3d 1362, 1363-64 (Fed. Cir. 1999) (quoting HTSUS, supra note 3, subheading 9405.30.00).

218. Dependable Packaging Sols., Inc. v. United States, 757 F.3d 1374, 1378 (Fed. Cir. 2014) (quoting HTSUS, supra note 3, heading 7013).

219. Tradewind Farms, $31 \mathrm{Ct}$. Int'l Trade at 665 (quoting HTSUS, supra note 3, subheading 9817.00.50).

220. E.M. Chems. v. United States, 20 Ct. Int'1 Trade 382, 386-87 (1996).

221. 748 F.2d 663, 667 (Fed. Cir. 1984).

222. Id

223. HTSUS, supra note 3, subheading 2105.00

224. Id. ch. 4.

225. Id. heading 0207.

226. Stewart-Warner Corp., 748 F.2d at 667. 
using the lengthy Carborundum factors or following the requirements of Additional U.S. Rule 1(b), depending on whether it implies a principal or actual use. In addition to the extra judicial resources such a conclusion would demand, it may also lead to inaccurate classifications. For instance, the first Rule 1(b) requirement is that the goods are "intended" for the actual use at the time of importation. ${ }^{227}$ Imposing such a requirement may result in obviously edible foods, such as the gelatin in Puttmann imported "for technical purposes," being mistakenly classified as inedible.

The word edible is "purely descriptive," thus classifications in which it appears should be considered eo nominee provisions rather than use provisions. Granted, edible arguably implies a use, namely, being used for human consumption. However, a good is edible whether it is used for human consumption or not. The fact an apple is not eaten does not mean it is not edible. Similarly, to use the Stewart-Warner Corp. examples for "purely descriptive" adjectives, a "green" or "three-inch-indiameter" speedometer is still green or three inches in diameter no matter how it is used. ${ }^{228}$ Thus, headings or subheadings in which the word edible appears should be considered eo nominee provisions, free from the technical requirements of Additional U.S. Rules 1(a) or (b).

\section{b. Actually Eaten Test}

Although classifications with the word edible are very likely eo nominee provisions, if the harmful effects and habitually eaten tests do not settle whether a good is edible, the actual use of a good should determine the matter. If people actually eat a good after it is imported, the good is obviously edible, barring any reports of harmful effects attributable to the good. In effect, this is a slower and safer way to determine whether a good may be eaten without harmful effects. The test is slower because evidence as to whether a good is actually eaten after importation is not available at the time of importation; it comes in later. In addition, the actually eaten test is safer because no representatives of the importer, government, or court need test the unknown good. Lastly, the public will not be at risk either because food safety laws exist to weed out unsafe goods. ${ }^{229}$

An important issue with this test is that at the time of importation

227. HTSUS, supra note 3, Additional U.S. R. Interp. 1(b).

228. Stewart-Warner Corp., 748 F.2d at 667.

229. What We Do, FOOD \& DRUG ADMIN., http://www.fda.gov/aboutfda/whatwedo/ (last updated Aug. 5, 2014). 
there will not be evidence as to whether the good was actually eaten. This creates difficulty in determining whether the good is edible for purposes of tariff assessment. To resolve this issue, two different approaches should be taken: one if a good's tariff rate would be lower if considered edible, the other if a good's tariff rate would be higher if considered edible. First, if a good would receive a lower rate if considered edible, it should be presumed inedible and given the higher rate because an importer is in the best position to come back later with evidence that the good was actually eaten, in which case the extra money paid can be returned. For instance, the importer in Puttmann recovered his money by providing evidence that the gelatin, initially considered inedible, was served to guests in a New York hotel. ${ }^{230}$ Second, if a good would receive a higher rate if considered edible, the good should be presumed edible. Once again, this is because the importer is in the best position to know how the goods were actually used. The importer can come back later with evidence that the goods were never eaten, that they were put to other use(s), and the extra money paid can be returned.

\section{Edible at Time of Importation}

One last issue in determining whether a good is edible is that goods are classified "at the time of importation." 231 This requirement, on its face, seems to require that a good must be edible at the time of importation in order to be classified in a heading or subheading that contains the word edible. Thus, for instance, imported raw frozen meat arguably would not be considered edible. The dissent in P. John Hanrahan relied on this rule to conclude that wheat gum gluten, which was used as an ingredient in bread but could not be swallowed in its imported form, should be considered inedible and classified accordingly. ${ }^{232}$

However, a good should be considered edible if it is eventually edible, even if it is not technically edible "at the time of importation." First, a narrow interpretation of "at the time of importation" would render far too many obviously edible goods inedible. Many goods require cooking of some sort before they may be eaten without harmful effects. Second, case law seems to support this broader interpretation of

230. See United States v. Puttmann, 21 C.C.P.A. 135, 136 (1933).

231. United States v. P. John Hanrahan, Inc., 45 C.C.P.A. 120, 124 (1958) ("It is, of course, true, as urged by appellee, that classification must be determined on the basis of the condition of the merchandise at the time of importation ....").

232. Id. at 125 (Worley, J., dissenting). 
"at the time of importation." For instance, the majority in P. John Hanrahan acknowledged the rule that a good must be edible at the time of importation, but held that wheat gum gluten satisfied this requirement because it would ultimately be used in an edible good. ${ }^{233}$ The court in Barad Shaff reaffirmed this reasoning, holding that Junex was edible because it was ultimately used in ice cream. ${ }^{234}$ Third, this interpretation finds some indirect support in the Explanatory Notes. Explanatory Note (A) to heading 2106, which covers "food preparations not elsewhere specified or included," says that the heading includes "[p]reparations ... after processing (such as cooking, dissolving or boiling in water, milk, etc.). ${ }^{235}$

\section{CONCLUSION}

Edible is a common word in the HTSUS, and whether a good is edible can substantially affect its tariff classification and the rate the good receives. Thus, the question of whether a good is edible has important economic ramifications. As an example, in Puttmann, the importer argued the gelatin in question was edible so that it would be classified as "edible gelatin," and given a tariff rate of " 20 per centum ad valorem and 7 cents per pound." 236 Meanwhile, the government argued the gelatin was inedible so that it would be classified as "gelatin ... not specially provided for," and given a tariff rate of " 25 per centum ad valorem and 8 cents per pound." 237 The importer imported 2,000 pounds of gelatin and its value was over 40 cents per pound. ${ }^{238}$ Thus, if the gelatin was considered edible, and assuming its value was exactly 40 cents, the importer would pay $\$ 300$. Meanwhile, if the gelatin was considered inedible, the importer would pay $\$ 360$, sixty dollars more than if considered edible. Sixty dollars in 1933, when the gelatin was imported, is worth about one thousand dollars today. ${ }^{239}$ Thus, classification of a good as edible can significantly affect both how much the government may collect and how much an importer must pay.

Determining whether a good is edible is not as easy as it may

\footnotetext{
233. Id. at 124 (majority opinion).

234. Barad Shaff Sales Co. v. United States, 56 Cust. Ct. 447, 449 (1966).

235. World Customs Organization Explanatory Notes, GLOBAL TARIFF, http://www.global tariff.net (last visited Jan. 10, 2015).

236. United States v. Puttmann, 21 C.C.P.A. 135, 136 (1933).

237. Id.

238. Id.

239. Inflation Calculator, DOLLAR TIMES, http://www.dollartimes.com/calculators/inflation.htm (last visited Oct. 3, 2015).
} 
initially seem. Courts have used, and parties have argued for, a wide variety of factors to determine whether a good is edible. However, there are several factors that should not be used in determining whether a good is edible. These factors include whether the good is eatable, whether it appears edible to the senses, whether the good provides nourishment, whether the constituent parts of the good are edible, and whether the good's principal use is as food.

Instead, only a few factors need be considered to determine whether a good is edible. First, if the good may be eaten without harmful effects, then it should be considered edible. Such a definition accords most closely to the common meaning of edible, which is important because the common meaning of HTSUS terms controls absent a statutory definition or commercial meaning. ${ }^{240}$ In addition, the harmful effects test effectively serves to differentiate between edible and inedible goods. Second, if testing a good for harmful effects could put anyone in danger, the good should be considered edible if it is habitually eaten. If a good is habitually eaten, it practically guarantees the harmful effects test is met. In addition, the habitually eaten test finds significant support in the case law. Lastly, if neither of these tests produces a definitive result, the good should be considered edible if it is actually eaten. This test can determine whether a good may be eaten without harmful effects, but in a slower and safer method. In addition, the actually eaten test avoids the complexities of Additional U.S. Rules 1(a) and (b).

This three-part definition provides a clear, simple, and accurate process by which to determine whether a good is edible. Such a definition will allow importers to better predict whether their good is edible and the government to more accurately determine whether a good is edible. The public at large benefits from a clear, simple, and accurate definition of edible in numerous ways. For instance, importers incur fewer unexpected costs, which may be passed on to consumers, the customs process (paid for by taxpayer dollars) is streamlined, and fewer classification decisions are administratively or judicially challenged. Thus, contrary to the contention of the court in Puttmann that "[d]efinitions of the word 'edible' are scarcely essential,",241 defining the word edible truly is essential.

240. Simmon Omega, Inc. v. United States, 83 Cust. Ct. 14, 20 (1979).

241. Puttmann, 21 C.C.P.A. at 137. 